Vegetation of the Arabian Peninsula 


\section{Geobotàny 25}

Series Editor

M.J.A. WERGER

The titles published in this series are listed at the end of this volume. 


\title{
Vegetation of the Arabian Peninsula
}

\author{
edited by
}

\author{
Shahina A. Ghazanfar \\ and \\ Martin Fisher \\ Department of Biology, \\ Sultan Qaboos University, \\ Muscat, Oman
}

Springer-Science+Business Media, B.V. 
A C.I.P. Catalogue record for this book is available from the Library of Congress.

\section{All Rights Reserved}

(C) 1998 Springer Science+Business Media Dordrecht

Originally published by Kluwer Academic Publishers in 1998

No part of the material protected by this copyright notice may be reproduced or utilized in any form or by any means, electronic or mechanical, including photocopying, recording or by any information storage and retrieval system, without written permission from the copyright owner 


\section{Contents}

Contributors vii

Preface ix

Chapter 1 Introduction 1

Shahina A Ghazanfar \& Martin Fisher

Chapter 2 Climate

Martin Fisher \& David A Membery

Chapter 3 Geology and Geomorphology

Ingeborg Guba \& Ken Glennie

Chapter 4 Biogeography and Introduction to Vegetation

Harald Kürschner

Chapter 5 Bryophytes and Lichens

Harald Kürschner \& Shabina A Ghazanfar

Chapter 6 Montane and Wadi Vegetation

Ulrich Deil, with Abdul-Nasser al Gifri

Chapter 7 Vegetation of the Plains

175

Shabina A Ghazanfar

Chapter 8 Vegetation of the Sands

James P Mandaville

Chapter 9 Coastal and Sabkha Vegetation

Ulrich Deil

Chapter 10 Water Vegetation 
Chapter 11 Plants of Economic Importance Shabina A Ghazanfar

Chapter 12 Diversity and Conservation

265

Martin Fisher, Shabina A Ghazanfar,

Shaukat A Chaudhary, Philip J Seddon, E Fay Robertson, Samira Omar, Jameel A Abbas \& Benno Böer

References

Index 


\section{Contributors}

Abdul-Nasser Al Gifri

Block 50, Blgd 13-201, Mansoora, Aden, Yemen.

Benno Böer

Ecology Department, National Avian Research Centre, PO Box 9903, Sweihan, United Arab Emirates

David Membery

Department of Meteorology, Directorate General of Civil Aviation and Meteorology, Seeb International Airport, PO Box 204 Seeb 113, Oman

E Fay Robertson

King Khaled Wildlife Research Center, National Commission for Wildlife Conservation and Development, PO Box 61681, Riyadh 11575,

Saudi Arabia

Harald Kürschner

Institut für Systematische Botanik und Pflanzengeographie,

Freie Universität Berlin, Altensteinstr. 6, 14195 Berlin, Germany

\section{Ingeborg Guba}

Department of Petroleum and Mining Engineering,

Sultan Qaboos University, PO Box 33 Al Khod 123, Muscat, Oman

Jameel A Abbas

Environmental Research Centre, University of Bahrain, PO Box 32038, Bahrain

James P Mandaville

10150 N. Calle del Carnero, Tucson, Arizona 85738, USA

Ken Glennie

Department of Geology and Petroleum Geology, University of Aberdeen, Aberdeen AB24 3UE, Great Britain 
Martin Fisher

Department of Biology, Sultan Qaboos University,

PO Box $36 \mathrm{Al}$ Khod 123, Muscat, Oman

PhilipJ Seddon

National Wildlife Research Center, National Commission for Wildlife

Conservation and Development, PO Box 1086, Taif, Saudi Arabia

Samira Omar

Kuwait Institute for Scientific Research, PO Box 24885,

13109 Safat, Kuwait

Shabina A Ghazanfar

Department of Biology, Sultan Qaboos University,

PO Box 36 Al Khod 123, Muscat, Oman

Shaukat A Chaudhary

Ministry of Agriculture and Water Resources, PO Box 17285,

Riyadh 11484, Saudi Arabia

Ulrich Deil

Biologisches Institut II/Geobotanik, Schänzlestr. 1, 79104 Freiburg, Germany 


\section{Preface}

The inspiration for this book came from our ten years of journeys and wanderings through the varied landscapes of Arabia, and in particular through those of its hospitable southeastern corner, Oman. We owe a particular debt to Sultan Qaboos University, which during this time has provided us with both a stimulating working environment and a home.

Transliteration of Arabic place and other names into English script is a task fraught with difficulties. We have followed 'accepted' spellings wherever these were not contrary to our common sense, and in other cases we have rendered names into Roman English script using phonetic spellings. Our main task in this respect was to ensure conformity between the fifteen contributing authors. Diacritical signs have mostly been avoided, since their use is neither widely followed nor readily understood.

Arabic words which have been commonly taken into the English language, such as 'sabkha' for a salt flat and 'wadi' for a valley with a seasonal watercourse, are not italicised in usage. However, other Arabic terms which are occasionally used in English but not as widely known, such as harrah for a basaltic lava field and hima for a traditional grazing reserve, are italicised throughout the text.

We are deeply indebted to the following scholars and enthusiasts for their various and invaluable contributions to this book: Andrew S. Gardner for his critical comments on Chapters 2, 3 and 12, Bruno Mies for critical comments on Chapter 5, Vic Hichings for his help with Chapter 3, Marinus Werger, the series editor, for his critical and encouraging comments on all chapters, and Ralph $\mathrm{H}$ Daly, Andrew Spalton, Ali al Kiyumi, David Insall and Mani Grobler for their help with the Oman section of Chapter 12.

In addition, we thank the Darwin scholar Duncan Porter for tracking down the quote at the beginning of Chapter 1, Michael Gallagher for the use of the invaluable library at the Natural History Museum, Oman, Ross Hesketh for his immortal contribution to the appearance of this book by introducing us to the Galliard font, David Insall for advice on the transliteration of Arabic names into Roman English script, Lisa Garner for the preparation of the line figures in Chapter 8, Klaus Müller-Hohenstein for the use of unpublished data and maps in Chapter 6, and Gina Douglas, Librarian at the Linnean Society, London, for information on Ethelbert Blatter. For the provision of climatological data we thank the Directorate General of Civil Aviation and Meteorology, Seeb International Airport, Oman, the staff of the White Oryx Project, Oman, and the Meteorological and Environmental Protection Authority, Saudi Arabia. We are 
$\mathrm{X}$

indebted to SPSS for supplying a copy of SYSTAT version 7 which was used to prepare a number of the figures, Compaq Computer corporation for generously mending a computer, and the USGS for providing the satellite photograph for the front cover. The final layout for this book was prepared by Martin Fisher.

Shahina A Ghazanfar \& Martin Fisher, Sultanate of Oman, October 1997 